\title{
PARAMETER-PARAMETER FISIKA UNTUK MENGUNGKAP STRUKTUR STATIS BAWAH PERMUKAAN GUNUNGAPI
}

\author{
Syahrial Ayub1), Muhammad Zuhdi'1), Muhammad Taufik') \\ 1)Program Studi Pendidikan Fisika, PMIPA, Universitas Mataram, Mataram, NTB, Indonesia \\ Corresponding author: Syahrial Ayub \\ E-mail : syahrial_ayub@unram.ac.id
}

\section{Diterima 18 Maret 2021, Direvisi 25 April 2021, Disetujui 27 April 2021}

\begin{abstract}
ABSTRAK
Parameter-parameter fisika gunungapi diungkap dengan metode geofisika. Survei kakas gravitasi dan magnetik yang menghasilkan anomali positive bagi medan gravitasi dan magnetiknya, mengungkap struktur statis bawah permukaannya. Analisis tremor volkanik mengungkap dinamika internalnya. Gerakan-gerakan (aliran) fluida magma di dalam gunungapi menjadi sumber getar yang memancarkan gelombang seismik yang di sebut tremor volkanik. Lokasi, migrasi, daya pancar, bentuk geometri sistem pipa-kantong magma, periodisasi, model matematis dan sebagainya. Gempa volkanik yang disebabkan aktivitas magma dapat dijadikan indikator. Hasil pengeplotan posisi hiposenter dan episenter terhadap gempa volkanik yang terjadi, juga dapat mengungkap struktur statis bawah permukaan gunungapi.
\end{abstract}

Kata Kunci : parameter-parameter fisika gunungapi; struktur statis bawah permukaan

\begin{abstract}
Using methods of geophysics, physical parameters of volcano are described. Gravity and magnetic surveys yield positive anomaly on their fields, which can be interpreted as an accumulated material beneath the surface with certain values of its mass density and magnetic susceptibility. Analysis of volcanic tremor at the volcano to the knowledge of its internal dynamics. Fluid magma movements inside a volcano acts as source of vibrations which radiate sesmic wave called volcanic tremor. Location, migration, radiation power, geometry of magma chamber-pipe system, periodicities, mathematical models, etc. Volcanic earthquakes caused by magma activity can also be used as indicators. The results of the hypocenter and epicenter position of the volcanic earthquake that occurred, can also reveal the subsurface static structure of the volcano.
\end{abstract}

Keywords : physical parameters; subsurface static structure

\section{PENDAHULUAN}

Gunungapi adalah tempat keluarnya magma ke permukaan bumi. Magma merupakan suatu cairan pijar yang terdapat dalam lapisan kulit bumi dengan suhu tinggi (lebih dari $1000{ }^{\circ} \mathrm{C}$ ) (Bullard, 1984). Magma mempunyai sifat fisika dan kimia tertentu yang terdiri dari unsur-unsur pembentuk batuan. Gunungapi terdapat pada jalur-jalur tertentu di muka bumi ini, seperti ; 1) jalur punggungan tengah samudera. Daerah punggungan tengah samudera ini, adalah tempat terpisahnya atau mekarnya lempeng kulit bumi yang pecah saling menjauh antara lempeng yang satu dengan yang lainnya, terdorong oleh naiknya cairan magma ke permukaan bumi membentuk gunungapi; 2) jalur pertemuan dua buah lempeng kerak bumi. Tumbukan antara lempeng benua dengan lempeng samudera; dan 3) pada titik-titik panas di muka bumi tempat keluarnya magma di benua maupun di samudera (Kusumadinata, K. 1979). Direktorat vulkanologi \& mitigasi bencana geologi, (2001), Indonesia merupakan negara kepulauan dan terkenal sebagai negara yang mempunyai gunungapi terbanyak di dunia. Hal ini sebagian besar disebabkan karena Indonesia terletak pada pertemuan 3 lempeng kerak bumi, yaitu; 1) lempeng Erasia; 2) lempeng Indo-Australia; dan 3) lempeng Pasifik (Hendrasto. 1992). Akibat tumbukan ketiga lempeng ini, menimbulkan jalur gunungapi aktif yang memanjang $7000 \mathrm{~km}$ dari Aceh sampai Sulawesi Utara, melalui bukit barisan (30 buah), pulau Jawa (35 buah), pulau Bali sampai kepulauan Nusa Tenggara (30 buah), kepulauan Maluku (16 buah), dan Sulawesi (18 buah). Sepanjang jalur tersebut, terdapat hampir $13 \%$ dari gunungapi dunia, yaitu 129 buah gunungapi yang dikategorikan aktif. Aktivitas gunungapi dibedakan menjadi dua jenis, yaitu aktivitas terlihat dan yang tidak terlihat oleh mata. Keluaran uap air putih, asap hitam, pembentukan kubah lava, aliran lava, meluncurnya awan panas, letusan dan 
sebagainya, yang semuanya itu terkait menjadi kesatuan aktivitas yang dinamakan erupsi gunungapi. Inilah yang merupakan jenis aktivitas yang terlihat. Sedangkan, gerakangerakan magma (lelehan batuan di dalam gunungapi) yang berupa aliran dengan bermacam-macam bentuk seperti monopol, dipol, quadrupol dan sebagainya (Kirbani, 1983), yang merupakan aktivitas yang tidak terlihat. Aktivitas yang terlihat merupakan indikasi adanya aktivitas yang tak terlihat, tetapi walaupun demikian aktivitas yang tidak terlihat tidak selalu dibarengi oleh aktivitas yang terlihat (Telford, W.M., Geldart, L.P., \& Sheriff, R.E., 1990). Bagi gunungapi, kedua jenis aktivitas tersebut sama sama pentingnya, sedangkan bagi penduduk yang hidup di sekitarnya aktivitas yang terlihatlah yang langsung mempengaruhi jalan hidupnya. Aktivitas yang terlihat dari gunungapi ini bisa memberikan dampak yang baik dan juga dampak yang tidak baik bagi penduduk di sekitar gunungapi tersebut. Daerah di sekitar gunungapi adalah daerah yang subur yang memberi kehidupan pada mereka, tetapi aliran lava panas/dingin juga bisa mengancam jiwa mereka. Olehkarena itu, pengetahuan kegunungapi-an sangat diperlukan untuk kesejahteraan dan juga keselamatan manusia. Fisika gunungapi merupakan penerapan ilmu dan metode fisika untuk mempelajari gunungapi dan penanaman konsep fisika dari fenomena yang terjadi di gunungapi. Bagi para fisikawan terutama geofisikawan, gunungapi ini sangat merangsang untuk disingkap parameterparameter fisikanya. Salah satu pertanyaan yang muncul adalah; bagaimanakah menentukan struktur statis di dalam gunungapi dengan parameter-parameter fisika yang diungkap.

\section{METODE PENELITIAN}

Pertanyaan yang muncul di pendahuluan pada artikel ini, dijawab dengan melakukan penelitian studi pustaka tentang permasalahan yang muncul. Penelitian studi pustaka adalah kegiatan untuk menghimpun informasi yang relevan dengan topik atau masalah yang menjadi obyek penelitian. Dengan melakukan studi kepustakaan, peneliti dapat memanfaatkan semua informasi dan pemikiranpemikiran yang relevan dengan penelitiannnya. Data didapatkan dari buku, buku referensi, artikel dan jurnal ilmiah yang dianalisis berdasarkan pengalaman dan pengetahuan penulis. Adapun prosedur yang dilakukan pada penelitian studi pusataka ini meliputi; 1) menggali ide umum tentang penelitian; 2) mencari informasi yang mendukung topik penelitian; 3) mempertegas fokus penelitian dan mengorganisasi bahan yang sesuai; 4) Mencari dan menemukan sumber data berupa sumber pustaka utama yaitu buku dan artikel artikel jurnal ilmiah, 5) melakukan reorganisasi bahan dan catatan simpulan yang didapat dari sumber data; 6) melakukan review atas informasi yang telah dianalisis dan sesuai untuk membahas dan menjawab rumusan masalah penelitian; 7) memperkaya sumber data untuk memperkuat analisis data dan 8) menyusun hasil penelitian. Data penelitian yang di ambil dari studi pustaka ini adalah data gunung Merapi yang terletak di perbatasan Daerah Istimewa Yogyakarta dan Jawa Tengah.
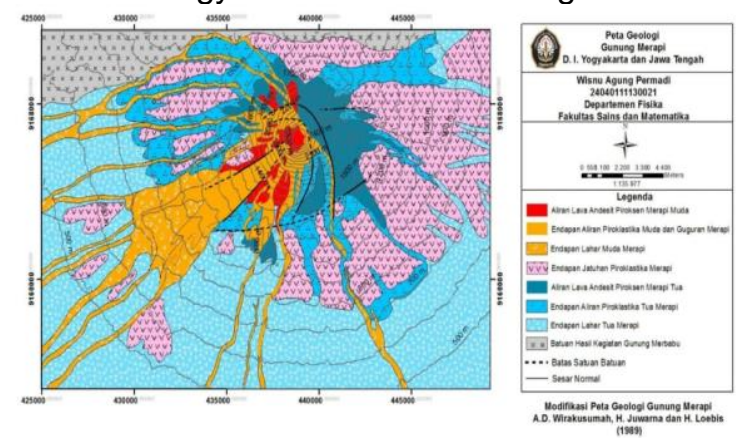

Gambar 1 : Lokasi penelitian pada peta Geologi gunung Merapi (Wirakusumah, 1989)

\section{HASIL DAN PEMBAHASAN}

Bagaimana mengungkap struktur statis bawah permukaan gunungapi?, untuk menjawab pertanyaan ini penulis mendapatkan data dari tinjauan pustaka yang dapat diuraikan. Proses letusan gunungapi mengeluarkan magma. Magma merupakan zat alir yang dinamis (dynamic magma fluid). Dinamika fluida ini sebagian besar tidak terlihat (invisible), dan hanya saat-saat erupsi saja terlihat sebagai letusan, semburan dan aliran lava. Sebagian besar aliran magma berada di dalam gunungapi, maka dicari besaran fisika yang dapat diukur yang merupakan gejala akibat aliran magma itu. Secara mekanis, ditemukan gejala bunyi (akustik) dan gejala perubahan bentuk (deformasi). Gelombang bunyi yang dapat didengar manusia sangat terbatas jangkauannya akibat mudah diserap oleh medium perantara. Solusinya digunakan gelombang seismik sebagai gejala yang dapat diamati. Gelombang seismik adalah gelombang infra-bunyi yang berfrekuensi lebih rendah dari batas ambang bawah gelombang bunyi. Deformasi akibat dinamika magma dapat langsung diamati karena menyangkut pengukuran, analisis perubahan posisi dan kemiringan (tilt). Disamping kedua gejala ini, masih terdapat besaran fisika yang dapat dikorelasikan dengan dinamika internal gunungapi. Besaran fisika tersebut adalah perubahan gravitasi mikro, medan geomagnetik, 
dan suhu. Jadi terdapat beberapa metode yang dapat dipakai mendapatkan parameterparameter fisika untuk mengungkapkan struktur statis bawah permukaan gunungapi, yaitu metode kakas gravitasi, seismik, geolistrik, medan magnetik dan elektromagnetik. Sebagai contoh gunung Merapi yang terletak di sebelah Utara $(30 \mathrm{~km})$ dari kampus UGM, merupakan salah satu gunungapi paling aktif di dunia. Pada gunung ini telah dilakukan 3 metode untuk mengungkapkan struktur statis bawah permukaannya. Metode itu adalah kakas gravitasi, medan magnetik dan seismik. Dengan mengukur besaran-besaran fisika kakas gravitasi, medan magnetik dan seismik, pada beberapa tempat di kawasan gunung Merapi, akan dihasilkan peta peta anomali medan gravitasi dan magnetik serta hiposenter dan episenter gempa volkanik. Anomali medan gravitasi berarti penyimpangan terhadap medan utama bumi secara global. Anomali medan gravitasi dapat positive atau negative. Anomali medan gravitasi positive berarti adanya akumulasi massa batuan dengan masaa jenis lebih besar dari pada rerata massa jenis di sekitarnya. Anomali medan magnetik positive berarti adanya akumulasi batuan yang bersuseptibilitas magnetik lebih besar dari batuan di sekitarnya. Peta anomali medan gravitasi dan magnetik penafsiran perlu dilakukan beberapa koreksi antara lain, koreksi ketinggian (elevasi), koreksi pengaruh bentuk permukaan tanah daerah survei, koreksi pengaruh variasi medan harian dan sebagainya. Setelah peta-peta anomali medan gravitasi dan magnetik diperoleh, penafsiran baru dapat dilaksanakan. Penafsiran adalah merupakan penyelesaian soal balik (inverse problem) yang pada prinsipnya tidak tunggal (non unique). Penafsiran juga dapat dilakukan dengan pembuatan model yang tanggapnya dapat dihitung dan ketidakcocokan nya dengan data anomali medannya dapat ditentukan. Model terbaik dipilih dengan kriteria nalar secara geologis, dan mempunyai ketidakcocokan dengan data minimum. Survei gravitasi dan magnetik di daerah gunung Merapi menghasilkan peta anomali yang positive. Penafsiran hasil survei tersebut berupa akumulasi batuan andesit basit. Menurut Suyanto (2012) dalam penelitian bawah permukaan gunung Merapi dan Merbabu menggunakan metode magnet, secara umum di bawah gunung Merapi terdapat 3 lapisan batuan. Lapisan pertama merupakan batuan piroklastik hasil aktivitas Merapi pada masa lalu, lapisan kedua berkaitan dengan posisi kantong magma, dan lapisan ketiga adalah lapisan yang mensuplai magma di atasnya. Lapisan ini bisa dilihat pada Gambar 2

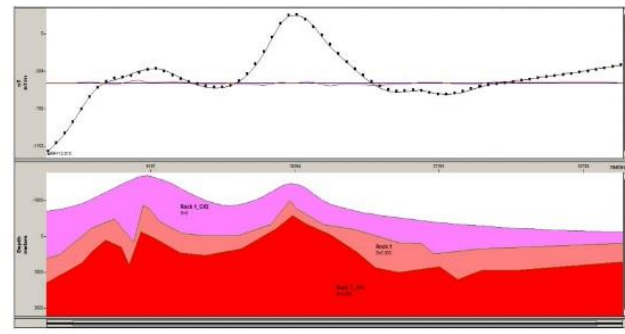

Gambar 2 : Model bawah permukaan anomali medan magnet gunung Merapi, Merbabu dan sekitarnya (Suyanto, 2012)

Model bawah permukaan di bawah gunung Merapi dan Merbabu, terdiri dari 5 perlapisan batuan, yaitu; 1) paling atas dengan densitas 2,15 gr/cc adalah piroklastik hasil aktivitas gunung Merapi dan Merbabu, dengan ketebalan berkisar puluhan sampai ratusan meter. Ketebalan lapisan di sebelah utara gunung Merbabu lebih tipis bila dibandingkan dengan di sebelah selatan gunung Merapi, 2) di bawahnya terdapat lapisan dengan densitas $2,40 \mathrm{gr} / \mathrm{cc}$. Pola perlapisannya mempunyai kesamaan dengan lapisan di atasnya, sehingga lapisan ini diinterpretasi sebagai lapisan produk aktivitas gunung Merapi dan Merbabu, tetapi lebih tua, 3) di bawah kedua lapisan tersebut terdapat batuan dengan densitas 2,60 gr/cc. Di dalam batuan tersebut, terdapat kantong magma di bawah puncak gunung Merapi dan Merbabu, 4) di bawahnya terdapat lapisan ke empat, batuan dengan densitas $2,80 \mathrm{gr} / \mathrm{cc}$. Batuan inilah yang akan menjadi basement bagi batuan yang lain. Bidang batas lapisan batuan ini terletak pada kedalaman $5 \mathrm{~km} \mathrm{~s} / \mathrm{d} 8$ $\mathrm{km}$ di bawah msl. Bidang batas ini bervariasi dan menebal di bagian tengah, terutama di bawah gunung Merbabu, 5) yang paling bawah adalah lapisan batuan dengan densitas 3,00 $\mathrm{gr} / \mathrm{cc}$, terletak pada kedalaman $11 \mathrm{~km}$ di bawah msl. Selain kelima lapisan batuan tersebut, terdapat model kantong magma di bawah gunung Merbabu dan Merapi. Kantong magma gunung Merbabu mempunyai kedalaman 4,5 $\mathrm{km}$ di bawah puncak dengan densitas 2,75 $\mathrm{gr} / \mathrm{cc}$. Sedangkan di bawah Merapi terdapat 2 kantong magma, dengan kantong magma atas pada kedalaman 500 meter di bawah puncak, dan kantong magma bawah pada kedalaman $3,2 \mathrm{~km}$ di bawah puncak. Densitas kantong magma di bawah Merapi adalah 2,70 gr/cc. penjelasan ini dapat dilihat pada gambar 3 . 


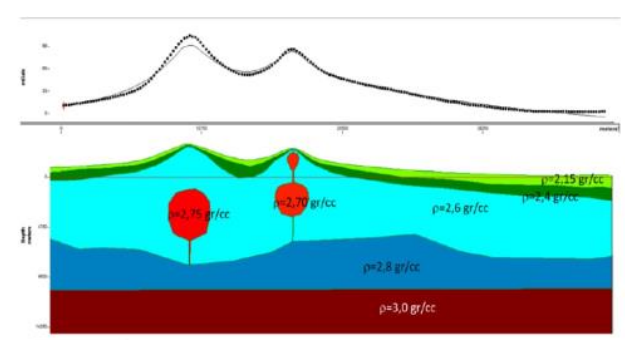

Gambar 3 : Model bawah permukaan anomali medan gravitasi gunung Merapi, Merbabu dan sekitarnya (Suyanto, 2011)

Struktur bawah permukaan yang diselidiki dengan metode geomagnetik dan gravitasi, menunjukkan adanya anomali benda dengan densitas lebih besar dan suseptibiltas lebih rendah dari batuan sekelilingnya di bawah Gunung Merapi pada kedalaman sekitar $3 \mathrm{~km}$ (Permadi, A., W., 2016). Dari hasil interpretasi data geomagnet di daerah Gunung Merbabu didapatkan sumber anomaly magnetik antara Gunung Merbabu yang lebih dalam (Situmorang, 1989). Hal ini dapat digunakan untuk alasan adanya perbedaan aktivitas antara kedua gunung tersebut. Penelitian dengan AMT (Audio Magneto Tellurik) menunjukkan adanya daerah-daerah dengan harga tahanan jenis yang rendah yang dapat dihubungkan dengan keberadaan kantong magma di Gunung Merapi (Arsadi, 1995). Fadeli, 1987, pada kedalaman $1 \mathrm{~km}$ terdapat kantong magma dangkal dan saluran di bawahnya yang menghubungkan dengan kantong magma yang lebih dalam. Seperti gambar 4 menunjukkan interpretasi bawah permukaan gunung Merapi dengan beberapa macam metode.

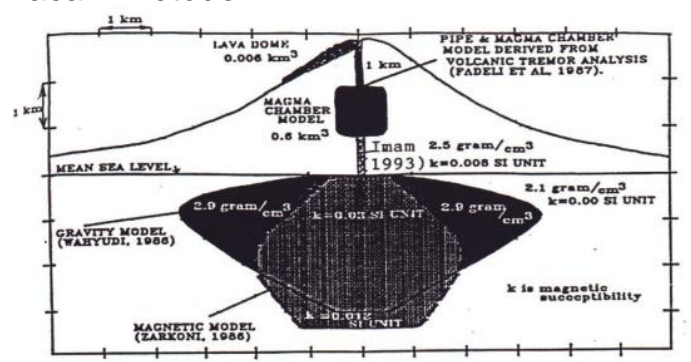

Gambar 4 : Hasil interpretasi bawah permukaan gunung Merapi dari beberapa macam metode (after Imam et al, 1993)

Ayub, S. (2009), sebaran gempa volkanik pada kedalaman dan permukaan (hypocenter and epicenter) dapat menjadi indikasi posisi kantong magma dan saluran magma. Gempa volkanik terjadi akibat aktivitas magma sehingga posisi hiposenter merupakan letak magma itu berada. Ayub, S. (2020), dengan metoda seismik mendapatkan episenter gempa volkanik cenderung mengumpul di sekitar puncak gunung merapi, dengan hiposenter gempa volkanik terdistribusi pada kedalaman $1200 \mathrm{~m}$ sampai $1300 \mathrm{~m}$ dari puncak gunung Merapi. Temuan ini mendukung hasil interpretasi bawah permukaan yang ditemukan oleh Imam et al, (1993).

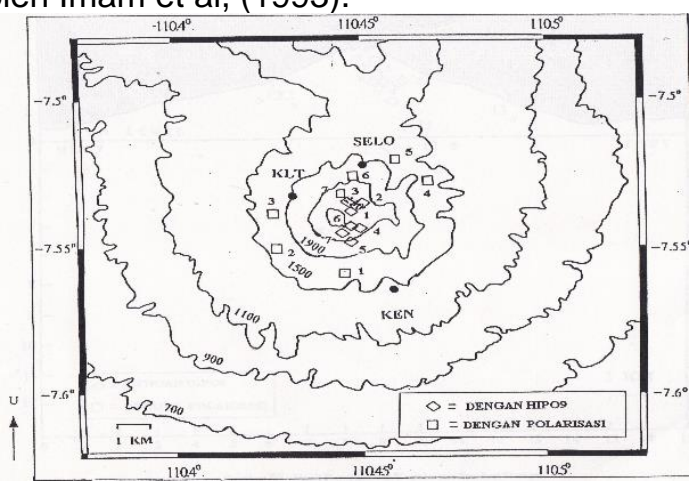

Gambar 5 : Sebaran episenter gempa volkanik gunung Merapi (Ayub, S., 2020)

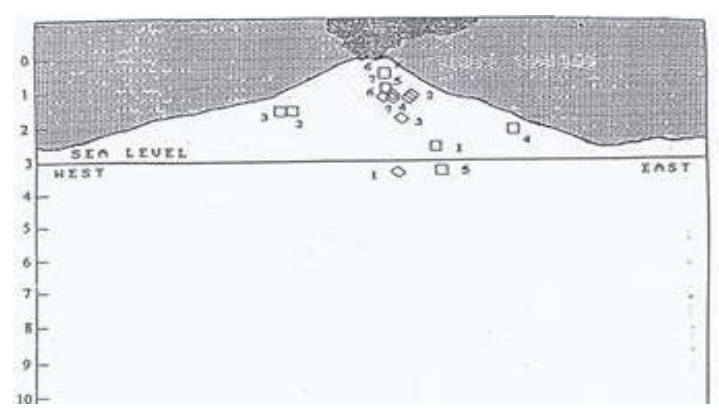

Gambar 6 : Sebaran hiposenter gempa volkanik gunung Merapi (Ayub, S., 2020)

Metode kakas gravitasi dan medan magnet dapat menafsirkan luas saluran dan kantong magma serta batuan-batuan pembentuk gunungapi tersebut (Sarkowi, M., 2014). Metode seismik mampu menguatkan penafsiran bentuk statis bawah gunungapi ini (Wahyudi. 1991). Jadi setiap metode dalam fisika yang menampilkan parameter dari perubahan besaran besaran fisika saling menguatkan dan berhubungan antara satu dengan yang lain.

\section{SIMPULAN DAN SARAN}

Struktur statis di dalam gunungapi dapat diungkap dengan menggunakan parameterparameter fisika gunungapi diungkap dengan metode geofisika, yaitu metode kakas gravitasi dan magnetik serta seismik yang mampu menguatkan hasil interpretasinya.

\section{SARAN}

Berikut saran yang bisa diajukan peneliti pada peneliti-peneliti lain dan pihak-pihak terkait; 1) dilakukan penelitian dan pengambilan data langsung, metode kakas gravitasi, medan magnet dan seismik dengan pemodelan dilakukan tidak hanya pada satu sayatan saja, 
tetapi dengan membuat beberapa sayatan yang lain, sehingga hasil akhir dari pemodelan adalah model 3D, 2) dilakukan analisis dan penelitian yang sebenarnya dengan beberapa metode lainnya, misalkan AMT (Audio Magneto Tellurik), SVD (Second Vertical Derivative), FHD (First Horizontal Derivative), yang umumnya digunakan untuk memperjelas adanya struktur-struktur geologi, 3) sebaiknya kajian diperluas pada gunungapi aktif lainnya di Indonesia tidak hanya terpusat di Jawa saja penelitiannya.

\section{UCAPAN TERIMA KASIH}

Puji dan syukur kami panjatkan kepada Allah SWT, penelitian kajian pustaka ini telah dilaksanakan dengan baik dan lancar serta telah menghasilkan sebuah artikel. Data penelitian ini, banyak mengacu pada penelitianpenelitian yang dilakukan oleh Universitas Gadjah Mada Yogyakarta. Terima kasih pada Prof.Dr. Kirbani Sri Brotopuspito (alm) yang telah banyak memberikan ilmunya kepada penulis tentang ke-gunungapi-an dan in shaa Allah akan terus penulis kembangkan. Semoga menjadi amalan jariyah buat beliau. Terima kasih buat program studi pendidikan fisika FKIP Universitas Mataram yang banyak memfasilitasi penulis dalam mengembangkan keilmuan ini. Terakhir terima kasih buat Universitas Muhammadyah Mataram, khususnya jurnal Orbita UMMAT yang telah membantu penulis mempublikasikan artikel ini.

\section{DAFTAR RUJUKAN}

Ayub, S., (1999). "Perbandingan penentuan hiposenter gempa volkanik dengan analisis polarisasi dan HIPO9". Tesis Program Pasca Sarjana Universitas Gadjah Mada.

Ayub, S., (2020). "Penentuan Hiposenter dan Episenter Gempa Volkanik Gunung Merapi dengan HIPO9", Jurnal Orbita UMMAT, Vol. 6, No. 1, h. 124-128.

Ayub, S., (2020). "Determination of Mount Merapi Volcanic Earthquake Hypocentre by Using Seismic Wave Polarization Analysis", JoSSEd Journal Mataram University, Vol.1, No. 1, h.2125.

Arsadi, E.M., Suparka, S. and Nishimura, S., (1995), Subsurface structure of Merapi inferred form magnetikotelluric, gravimetric and magnetikic surveys, Paper presented at Merapi Decade Volcano International Workshop, October 5-9, Yogyakarta, Indonesia.

Bullard, F. M. (1984). Volcanoes of the Earth. Austin: University of Texas Press.
Direktorat vulkanologi \& mitigasi bencana geologi. (2001). Pengetahuan Dasar Gunungapi Indonesia. Bandung : Departemen energi dan sumber daya mineral.

Fadeli. (1987). Pipe and Magma Chamber Model Derived from Volcanic Tremor Analysis. Laporan Penelitian,FMIPA UGM, Indonesia

Hendrasto. (1992). Gunungapi Merbabu dalam Edisi Khusus, Berita Berkala Vulkanologi. Bandung: Arsip Direktorat Vulkanologi.

Kusumadinata, K. (1979). Data Dasar Gunungapi Indonesia. Bandung: Direktorat Jenderal Pertambangan Umum dan Direktorat Vulkanologi.

Kirbani, S., (1983), "Analysis and interpretation of volcanic tremor at Etna (Sicily, Italy)". Publication No. 210, h. 1-106.

Permadi, A., W., (2016), "Interpretasi Bawah Permukaan Gunung Merapi dengan Analisis Gradient dan Pemodelan 2D Data Gaya Berat", Youngster Physics Journal, Vol. 5, No. 4, h. 433-440.

Suyanto, I. (2011). Pemodelan Bawah Permukaan Gunung Merapi dan Merbabu Berdasarkan Analisis Data Gravitasi. Yogyakarta: Laboratorium Geofisika, Jurusan Fisika, Universitas Gadjah Mada.

Suyanto, I. (2012). Pemodelan Bawah Permukaan Gunung Merapi Dari Analisis Data Magnetik dengan Menggunakan Software Geosoft. Yogyakarta: Laporan Penelitian Universitas Gajah Mada.

Sarkowi, M., (2014). Eksplorasi Gaya Berat. Yogyakarta: Graha IImu.

Telford, W.M., Geldart, L.P., \& Sheriff, R.E. 1990. Applied Geophysics 2nd Edition. Cambridge: Cambridge University Press.

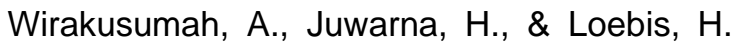
(1989). Peta Geologi Gunungapi Merapi, Provinsi Daerah Istimewa Yogyakarta dan Jawa Tengah. Yogyakarta : Departemen Energi dan Sumber Daya Mineral.

Wahyudi. (1991). "Studi tentang Karakteristik Sumber Gempa Volkanik di Gunung Merapi Jawa Tengah", Thesis. FakultasPascasarjana UGM, Yogyakarta. 